\title{
The mechanistic antitumor study of myricanol 5-fluorobenzyloxy ether in human leukemic cell HL-60
}

\author{
Guan-hai Dai ${ }^{*}{ }^{1,2}$, Chen-jie Fan ${ }^{3}$, Ze-ming Ren ${ }^{1}$, Xuan Chen ${ }^{1}$, Ye-ling Tong ${ }^{1}$, Zhen-hua Li ${ }^{3}$, \\ Xiao-jing $\mathrm{Nie}^{1}$ \& Ke-qun Chai ${ }^{* *}, 2$ \\ ${ }^{1}$ Institute of Basic Medicine, Zhejiang Academy of Traditional Chinese Medicine, Hangzhou, China \\ ${ }^{2}$ Institute of Cancer Research, Zhejiang Academy of Traditional Chinese Medicine, Hangzhou, China \\ ${ }^{3}$ College of Pharmaceutical Science, Zhejiang University of Technology, Hangzhou, China \\ * Author for correspondence: Tel.: +86 5718884 9082; daiguanhai@hotmail.com \\ ** Author for correspondence: Tel.: +86 5718997 2001; ckq_official@163.com
}

\begin{abstract}
Aim: The aim of the study was to explore the growth inhibitory effect of myricanol 5-fluorobenzyloxy ether (5FEM) and the underlying mechanism in human leukemic cells HL-60. Materials \& methods: 5FEM was obtained by chemical modification of myricanol with fluorobenzyloxy ether at the $\mathrm{OH}(5)$ position. The cytotoxicity, cell apoptosis, cell cycle and the expression of key apoptosis-related genes in HL-60 were evaluated. Results \& conclusion: 5FEM can significantly inhibited growth of HL-60 cells, increased the G2/M population and upregulated the expression of Bax, Fas, FasL, caspase-9 and p21 and downregulated that of $\mathrm{BCl}-2$ and survivin. The results enhance our understanding of 5FEM and aid the discovery of novel myricanol derivatives as potential antitumor agents.
\end{abstract}

First draft submitted: 24 July; Accepted for publication: 11 August; Published online: 18 August 2017

Keywords: antitumor • apoptosis • cell cycle • cell growth inhibition • myricanol 5-fluorobenzyloxy ether

The incidence and mortality of cancer have been increasing in China [1]. About 4,292,000 new cases of cancer and 2,814,000 cancer-related deaths were estimated in China in 2015 [2]. It was reported that leukemia is the sixth leading cause of cancer death [3].

Both genetic and environmental factors have been reported to cause of leukemia $[4,5]$. Combination of chemotherapy, radiation therapy and bone marrow transplant are involved in treatment of leukemia [6]. But these treatments have limitations because of a high probability of relapse and toxicity. Traditional Chinese medicine and natural plants have been used in the treatment of cancer for thousands of years in China. Owing to its minor side effects and good curative efficacy, the screening of anticancer drugs from traditional Chinese herbal medicine has increased considerably over the past few years $[7,8]$.

Myrica rubra (Lour.) Sieb. Et Zucc., a myricaceae Myrica plant, found in China and other Asian countries. Because of its biological properties, the bark of M. rubra is used in Chinese folk medicine [9-11]. Myricanol is a cyclic diarylheptanoid isolated from the bark of $M$. rubra. Diarylheptanoids exhibit various biological activities, including antitumor [12], antiviral [13], antioxidant [14] and anti-inflammatory [15] owing to its unique chemical structure. Our previous studies have shown that myricanol significantly inhibits the proliferation of human lung adenocarcinoma (A549), hepatoma (HepG2) and human promyelocytic leukemia (HL-60) cells. Further, it increased the caspase-3, caspase-9, Bax and p21 expression and decreased the expressions of Bcl-2 at the mRNA and protein levels [16]. Myricanol significantly induced tumor growth inhibitory effects on the xenografts of lung adenocarcinoma A549 by upregulating the expression of Bax and downregulating that of survivin, Bcl-2, VEGF and HIF-1 $1 \alpha$. The experimentation has indicated that the possible antitumor effects of myricanol are via the mitochondrial apoptosis pathway [17].

In order to improve anticancer effect of myricanol, and to further explore the structure-activity relationship of myricanol and discover novel myricanol derivatives as antitumor agents, some novel myricanol derivatives, such as 5-fluorobenzyloxy ether (5FEM), myricanol 5-chlorobenzyloxy ether and myricanol 5-bromobenzyloxy ether, were synthesized and evaluated against A549, HepG2 and HL-60 cancer cell lines. Among them, 5FEM was found to 
be more potent than myricanol against some cancer cell lines. The inhibitory effect on HL-60 cells was particularly evident. Chemical modification of myricanol by the introduction of fluorobenzyloxy ether at the $\mathrm{OH}(5)$ position resulted in increased activity and improved drug-like properties. These findings will enhance our understanding of 5FEM and aid the development of novel myricanol derivatives as potential antitumor agents. In this article, we just discuss the 5FEM, other compounds about myricanol derivatives and more details will be revealed in our another article, and will be submitted later.

\section{Materials \& methods \\ Reagents}

Tritiated thymidine $\left({ }^{3} \mathrm{H}-\mathrm{TdR}\right)$ was purchased from China Isotope \& Radiation Corporation. Cisplatin (DDP) injection was purchased from Qilu Pharmacy Co., Ltd. Annexin V-fluorescein isothiocyanate (V-FITC)/propidium iodide (PI) Apoptosis Assay kit was purchased from Zoman Bio Co., Ltd. Culture reagents including fetal bovine serum (FBS), Roswell Park Memorial Institute (RPMI) 1640 medium, Iscove's Modified Dulbecco's Medium (IMDM), phosphate-buffered saline (PBS) and 0.25\% trypsin were purchased from Gino Biological Pharmaceutical Technology Co., Ltd. Primary rabbit monoclonal antibodies against caspase-9, Bax, Bcl-2, FAS-L, p21 and actin were purchased from Epitomics. All other chemicals used were of analytical grade and were purchased from Sigma-Aldrich (MO, USA).

\section{Preparation of 5FEM}

Myricanol was extracted and detected as previously described [17]. Then, myricanol $(50.0 \mathrm{mg})$ was added to $5.0 \mathrm{ml}$ of acetone in a round-bottom flask, and was stirred until dissolved. $\mathrm{K}_{2} \mathrm{CO}_{3}(63.0 \mathrm{mg})$ was added, followed by mixing for $1 \mathrm{~h}$. Then, $85.0 \mathrm{mg}$ of 4 -fluorine benzyl bromide was added in the absence of light at $20^{\circ} \mathrm{C}$. The reaction products of myricanol were determined by thin-layer chromatography. The solvent was evaporated using a rotary evaporator. Thereafter, $0.1 \mathrm{~g}$ silica was added to the samples. Silica gel (300- to 400-mesh) was added to the column and pre-eluted three-times with petroleum ether, followed by sample loading. Liquid chromatography was conducted with petroleum ether:ethyl acetate at a ratio of 3:1. The products of chromatography were collected, combined and spin-dried. 5FEM $(57.0 \mathrm{mg})$ was obtained as a yellow solid. ${ }^{1} \mathrm{H}$ NMR $\left(400 \mathrm{MHz}, \mathrm{CDCl}_{3}\right) \delta$ (integration, multiplicity, $J(\mathrm{~Hz})$, position): 1.50-1.64 (3H, m, OH11, H9a, H10a), 1.67-1.78 $(2 \mathrm{H}, \mathrm{m}, \mathrm{H} 9 \mathrm{~b}$, H12a), 1.82-1.96 (3H, m, H $28, \mathrm{H} 10 \mathrm{~b}), 2.28-2.38$ (1H, m, 12Hb), 2.40-2.50 (1H, m, H7a), 2.72-2.81 (1H, m, H7b), 2.89-2.95 (2H, m, H $\left.\mathrm{H}_{2} 13\right), 3.93\left(3 \mathrm{H}, \mathrm{s}, \mathrm{H}_{3} 20\right), 3.98\left(3 \mathrm{H}, \mathrm{s}, \mathrm{H}_{3} 21\right), 4.06(1 \mathrm{H}, \mathrm{t}, 9.9, \mathrm{H} 11), 4.98(1 \mathrm{H}, \mathrm{d}$, 10.8, H22a), 5.13 (1H, d, 11.2, H22b), 6.89 (1H, s, H19), 6.91 (1H, d, 8.0, H16), 7.07 (1H, dd, 8.0, 2.0, H15), 7.08 (2H, m, H25, H27), 7.17 (1H, d, 2.0, H18), 7.44 (2H, m, H24, H28), 7.83 (1H, s, OH17); ${ }^{13} \mathrm{C}$ NMR (100 MHz, CDCl3) $\delta$ (position): 23.2 (C9), 26.3 (C7), 26.6 (C8), 27.3 (C13), 35.1 (C12), 39.8 (C10), 61.8 (2C, C20, C21), 68.8 (C11), 74.3 (C22), 115.5 (2C, C25, C27), 117.1 (C16), 124.6 (C6), 127.7 (C2), 129.3 (C1), 129.7 (C19), 130.4 (2C, C24, C28), 130.3 (C15), 130.8 (C14), 133.3 (C23), 133.6 (C18), 145.7 (C4), 147.2 (C3), 150.8 (C5), 151.7 (C17), 161.4 (C26); ESIMS m/z 465.2 [M -1]- (calcd for $\mathrm{C}_{28} \mathrm{H}_{30} \mathrm{FO}_{5}, 465.22$ ). We obtained 5FEM by controlling the strength of the base, reaction temperature and reaction time. With $\mathrm{K}_{2} \mathrm{CO}_{3}$, $20^{\circ} \mathrm{C}$ and proper reaction time, the product is 5FEM only. The content of 5FEM was $99.5 \%$ detected by HPLC. $5 \mathrm{FEM}$ at $100 \mathrm{mg} / \mathrm{ml}$ was dissolved completely in DMSO to obtain a stock solution, and diluted with medium before use. The final DMSO concentration did not exceed $0.1 \%$.

The chemical structure of myricanol and 5FEM is shown in Figure 1.

\section{Cell culture}

The human lung carcinoma A549 cell line, hepatocellular carcinoma HepG2 cell line and human leukemic HL-60 cell line were obtained from the Cell Bank of Chinese Academy of Sciences (Shanghai, China). A549 and HepG2 cells were cultured in RPMI-1640 medium. HL-60 cells were cultured in IMDM medium containing 10\% FBS, penicillin $(100 \mathrm{IU} / \mathrm{ml})$ and streptomycin $(100 \mu \mathrm{g} / \mathrm{ml})$ at $37^{\circ} \mathrm{C}$ in a humidified atmosphere of $5 \% \mathrm{CO}_{2}$. Cells were used for different assays during logarithmic growth phase while the untreated control cultures received only the vehicle (DMSO $<0.1 \%)$.

\section{Cytotoxicity assay}

The cytotoxic effect of 5FEM was measured using the ${ }^{3} \mathrm{H}-\mathrm{TdR}$ assay. A549, HepG2 or HL-60 cells $\left(5 \times 10^{3}\right.$ cells/well) were seeded in 96-well microtiter plates (Corning Life Sciences, NY, USA) and incubated for $24 \mathrm{~h}$ prior 
Figure 1. Chemical structures of compounds. (A) Chemical structure of myricanol. (B) Chemical structure of 5FEM.

5FEM: 5-fluorobenzyloxy ether.

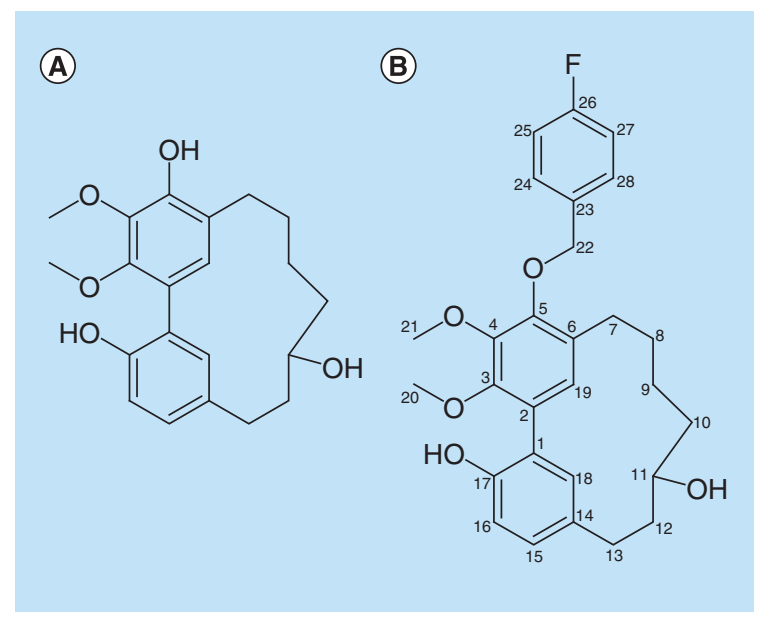

to treatment with 5FEM. 5FEM was dissolved in DMSO and diluted with the medium. After incubation at $37^{\circ} \mathrm{C}$ in a humidified incubator for $48 \mathrm{~h}$, each well was added with $0.5 \mu \mathrm{ci} / 50 \mu \mathrm{l}^{3} \mathrm{H}$-TdR, followed by $16 \mathrm{~h}$ incubation. After that, we collected the cells and determined the counts per minute by liquid scintillation counting (Micro Beta 2450, Perkin Elmer, MN, USA). The growth inhibitory effect of 5FEM was assessed as the percentage of cell viability. Assays were performed in three independent experiments.

\section{Cell apoptosis analysis by flow cytometry}

Briefly, HL-60 cells $\left(1.5 \times 10^{5} /\right.$ well $)$ were incubated in IMDM $+10 \%$ FBS in six-well plates for $24 \mathrm{~h}$. Then treated with different concentrations of 5 FEM $(1.25,2.5$ and $5.0 \mu \mathrm{g} / \mathrm{ml})$, myricanol $(5.0 \mu \mathrm{g} / \mathrm{ml})$, DDP $(5.0 \mu \mathrm{g} / \mathrm{ml})$ or vehicle $(0.1 \%$ DMSO) for $48 \mathrm{~h}$. Then cell apoptosis was detected and quantified by flow cytometry (FCM) as previously described [17].

\section{Cell cycle analysis by FCM}

HL-60 cells $\left(1.5 \times 10^{5} /\right.$ well $)$ were incubated in six-well plates in IMDM $+10 \%$ FBS for 24 h. Thereafter, cells were treated with different concentrations of 5FEM $(1.25,2.5$ and $5.0 \mu \mathrm{g} / \mathrm{ml})$, myricanol $(5.0 \mu \mathrm{g} / \mathrm{ml}), \mathrm{DDP}$ $(5.0 \mu \mathrm{g} / \mathrm{ml})$ or vehicle $\left(0.1 \%\right.$ DMSO) for $48 \mathrm{~h}$. The cells $\left(1 \times 10^{6}\right)$ were resuspended in $1000 \mu \mathrm{l}$ of cold PBS. Pellet cells were subjected to centrifugation at 1000 r.p.m., $4^{\circ} \mathrm{C}$ for $5 \mathrm{~min}$. Cells were fixed with $0.5 \mathrm{ml}$ of $70 \%$ ethanol for $2 \mathrm{~h}$ at $-20^{\circ} \mathrm{C}$. Afterward, cells were washed with PBS by centrifugation (as above). Then, $100 \mu \mathrm{l}$ of $200 \mu \mathrm{g} / \mathrm{ml} \mathrm{DNase-free} \mathrm{RNase} \mathrm{A} \mathrm{was} \mathrm{added} \mathrm{and} \mathrm{incubated} \mathrm{at} 37^{\circ} \mathrm{C}$ for $30 \mathrm{~min}$. Finally, $400 \mu \mathrm{of} 1 \mathrm{mg} / \mathrm{ml} \mathrm{PI}$ (light sensitive) was added and incubated at room temperature for 5-10 min. The samples were placed in Falcon tubes and analyzed by FCM (Model EPICS XL-4, Beckman Coulter, CA, USA). The experiments were performed in triplicate.

\section{Total RNA isolation \& quantitative real-time PCR analysis}

HL-60 cells were pretreated with different concentrations of 5FEM $(1.25,2.5$ and $5.0 \mu \mathrm{g} / \mathrm{ml})$, myricanol $(5.0 \mu \mathrm{g} / \mathrm{ml})$, DDP $(5.0 \mu \mathrm{g} / \mathrm{ml})$ or vehicle $(0.1 \%$ DMSO) for $48 \mathrm{~h}$. Total RNAs were isolated from cells using an E.Z.N.A. Total RNA Kit (Omega Bio-tech, Inc., GA, USA). cDNAs were synthesized using $1 \mu \mathrm{g}$ of total RNAs and using a First Strand cDNA Synthesis Kit (Gene Copoeia, MD, USA) and then used for RT-PCR analysis with SYBR premix EX Taq (TaKaRa, Shiga, Japan). The expression levels of target genes (caspase-3, caspase-9, Bax, Bcl-2 and $p 21)$ were normalized to those of GAPDH [18].

The cDNA fragment was amplified by PCR using following specific primers: caspase-3 forward, 5'-ATCACAGCAAAAGGAGCAGTTT-3'; caspase-3 reverse, 5'-ATCACAGCAAAAGGAGCAGTTT3'; caspase-9 forward, 5'-TCTGGAGGATTTGGTGATGTC-3'; caspase-9 reverse, 5'CATTTTCTTGGCATCAGGTC-3'; Bax forward, 5'-AAGCTGAGCGAGTGTCTCAAG-3'; Bax reverse, 5'-CAAAGTAGAAAAGGGCGACAAC-3'; $B c l-2$ forward, 5'-ATGTGTGTGGAGAGCGTCAAC$3^{\prime}$; Bcl-2 reverse, 5'-AGAGACAGCCAGGAGAAATCAAAC-3'; survivin forward, 5'AGGTCATCTCGGCTGTTCCTG-3'; survivin reverse, 5'-TCATCCTCACTGCGGCTGTC-3'; Fas forward, 


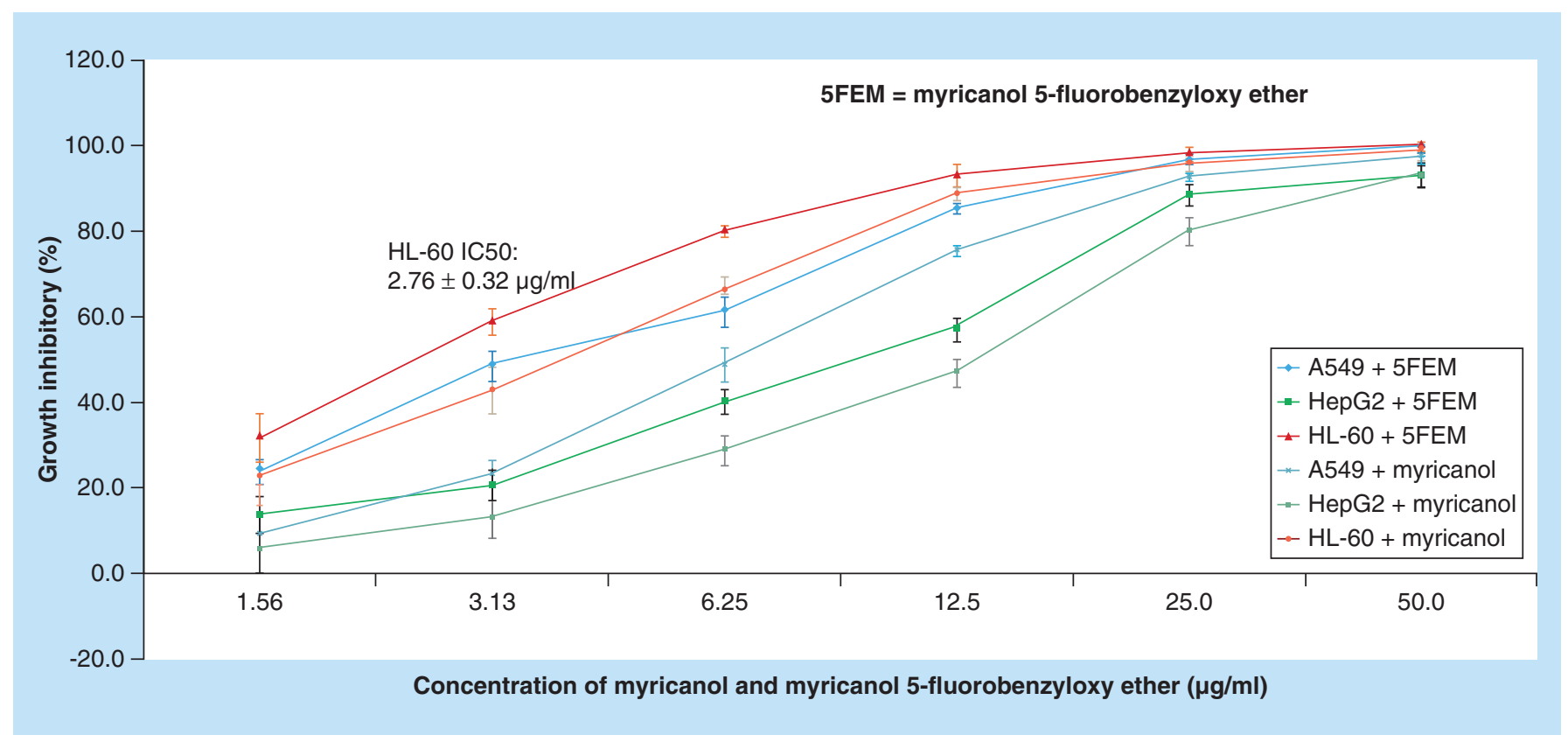

Figure 2. Growth inhibitory effect of myricanol and 5-fluorobenzyloxy ether on A549, HepG2 and HL-60 cells after 72 h of treatment.

5'-GAGTGAGGGAAGCGGTTTACG-3'; Fas reverse， 5'-GTCAGTCACTTGGGCATTAACAC-3'; FasL forward, 5'-CTGGGGATGTTTCAGCTCTTC-3'; FasL reverse, 5'-CTTCACTCCAGAAAGCAGGAC-3'; p21 forward, 5'-TTAGCAGCGGAACAAGGAGT-3'; $p 21$ reverse, 5'-AGAAACGGGAACCAGGACAC3'; GAPDH forward, 5'-GAGAAACCTGCCAAGTATGATGAC-3'; GAPDH reverse, 5'TAGCCGTATTCATTGTCATACCAG-3'. PCR was carried out in a thermal cycle programmed at $95^{\circ} \mathrm{C}$ for $5 \mathrm{~s}, 60^{\circ} \mathrm{C}$ for $30 \mathrm{~s}$ and amplified for 40 cycles. The amplified PCR products were visualized on $1.5 \%$ agarose gels.

\section{Western blot analysis}

HL-60 cells were pretreated with different concentrations of 5 FEM $(1.25,2.5$ and $5.0 \mu \mathrm{g} / \mathrm{ml})$ for $48 \mathrm{~h}$. The vehicle $(0.1 \%$ DMSO $)$ and DDP $(5.0 \mu \mathrm{g} / \mathrm{ml})$ acted as the negative and positive controls, respectively. The cells were harvested and lysed with a lysis buffer (10\% glycerol, $1 \mathrm{mM}$ leupeptin, $0.5 \% \mathrm{NP}-40,150 \mathrm{mM} \mathrm{NaCl}, 50 \mathrm{mM}$ Tris- $\mathrm{Cl}$ [pH 7.5], $1 \mathrm{mM}$ phenylmethylsulfonyl fluoride and $2 \mathrm{mM}$ dithiothreitol) on ice. The proteins were then quantified using a Bicinchoninic Acid Protein Assay Kit (Beyotime Biotechnology, Shanghai, China). A total of 30- $\mathrm{g}$ p protein were separated using $12-15 \%$ SDS-PAGE. Then Western blot experiments were carried out as previously described [17]. The results of Western blot analysis were evaluated using the Quantity One software.

\section{Statistical analysis}

Data are presented as mean \pm standard deviation of the indicated number of independently performed experiments. Statistical analysis was done using a one-way analysis of variance test. Asterisks indicated statistical significance as follows: ${ }^{*}, \mathrm{p}<0.05$; ${ }^{* *}, \mathrm{p}<0.01$; and ${ }^{* *}, \mathrm{p}<0.001$.

\section{Results}

Inhibition of the proliferation of A549, HepG2 \& HL-60 cells

The effect of 5FEM on the viability of A549, HepG2 and HL-60 cells was examined using the ${ }^{3} \mathrm{H}-\mathrm{TdR}$ assay. A549, HepG2 or HL-60 cells were seeded in 96-well microtiter plates and treated with different concentrations of 5FEM (at a final concentration range between $1.56 \mu \mathrm{g} / \mathrm{ml}$ and $50.0 \mu \mathrm{g} / \mathrm{ml}$ ) for $48 \mathrm{~h}$ in a humidified incubator. ${ }^{3} \mathrm{H}-\mathrm{TdR}$ was added to each well and incubated for $16 \mathrm{~h}$. The cells were collected, and the counts per minute were determined by liquid scintillation counting. 5FEM significantly inhibited the growth of all cells in a dose-dependent manner. The inhibitory effect on HL-60 cells was particularly evident, with a half-maximal inhibitory concentration $\left(\mathrm{IC}_{50}\right)$ 
(A)

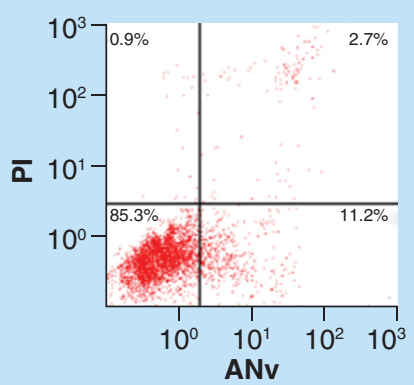

(E)

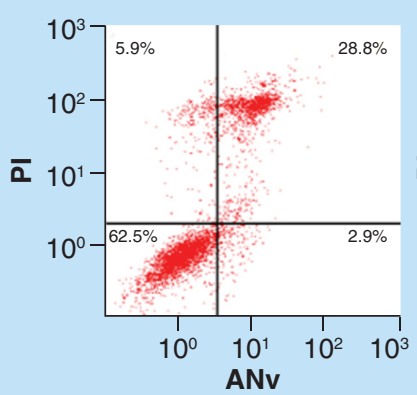

(B)

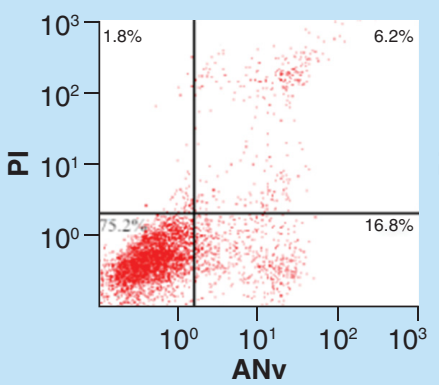

(C)

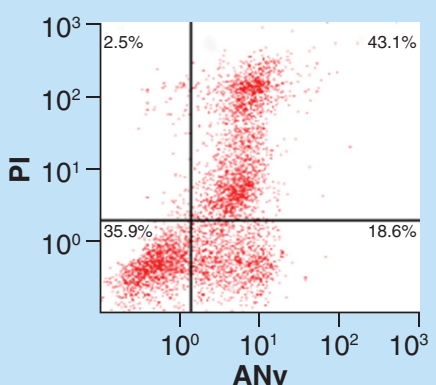

(D)

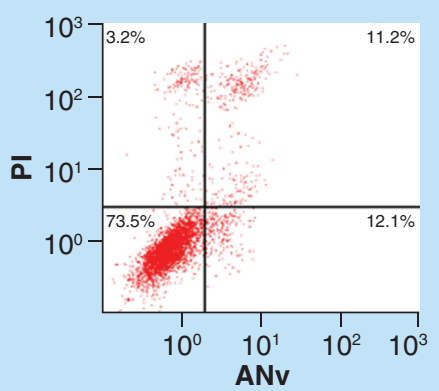

(F)

(G)
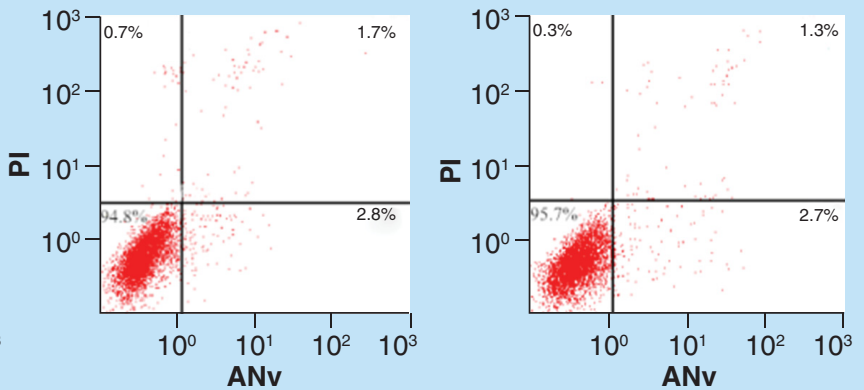

(1)

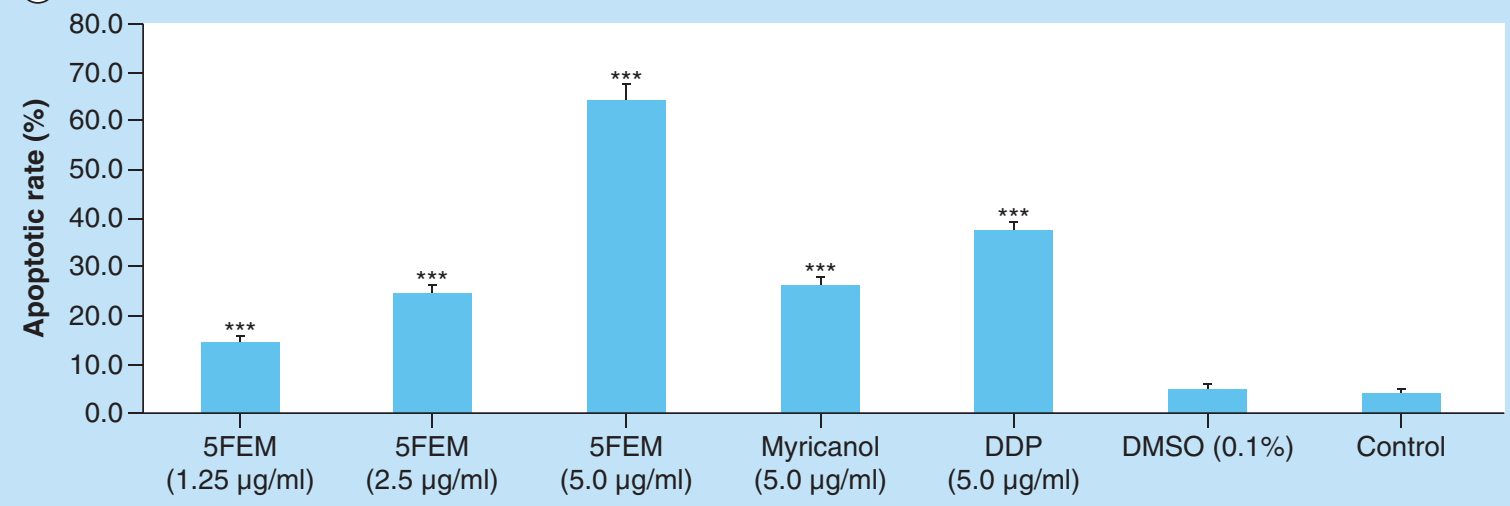

Figure 3. Effects of 5-fluorobenzyloxy ether on the apoptosis of HL-60 cells.

The cells were treated with different concentrations of $5 F E M$ for $48 \mathrm{~h}$, and were labeled with Annexin V-fluorescein isothiocyanate and

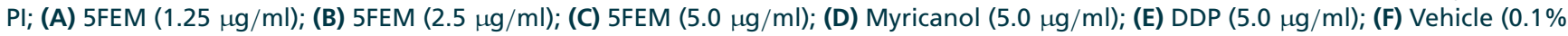
DMSO) control; (G) Iscove's Modified Dulbecco's Medium control. (H) Column figure of apoptotic rate in different groups. All data were expressed as mean $\pm \mathrm{SE}$ of three experiments and each experiment included triplicate repeats.

$* * * \mathrm{p}<0.001$ versus vehicle control.

5FEM: 5-fluorobenzyloxy ether; ANv: Annexin V; DDP: Cisplatin; DMSO: Dimethyl sulfoxide; PI: Propidium iodide.

of $2.76 \pm 0.32 \mu \mathrm{g} / \mathrm{ml}$ (Figure 2). The results also showed that the antitumor effect of 5FEM was better than that of myricanol.

\section{Flow cytometric apoptosis assay}

Because the inhibitory effect on HL-60 cells was particularly evident for 5FEM, we only choose HL-60 cell line for the rest study. HL-60 cells were treated with different concentrations of $5 \mathrm{FEM}(1.25,2.5$ and $5.0 \mu \mathrm{g} / \mathrm{ml})$ for $48 \mathrm{~h}$. The apoptosis induced by 5FEM was quantified by FCM, after cell labeling with Annexin V-FITC and PI (Figure 3). The apoptotic rate increased from $4.3 \%$ (untreated cells) to $64.1 \%$ (treated with $5.0 \mu \mathrm{g} / \mathrm{ml}$ FFEM). It 
(a) ลั

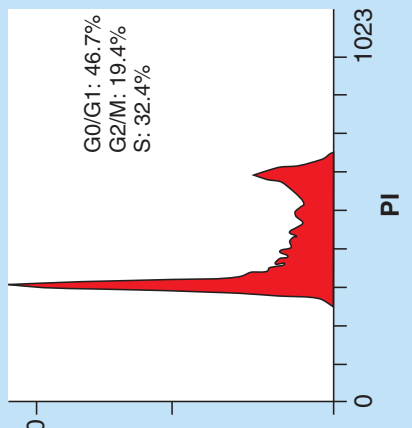

(4)
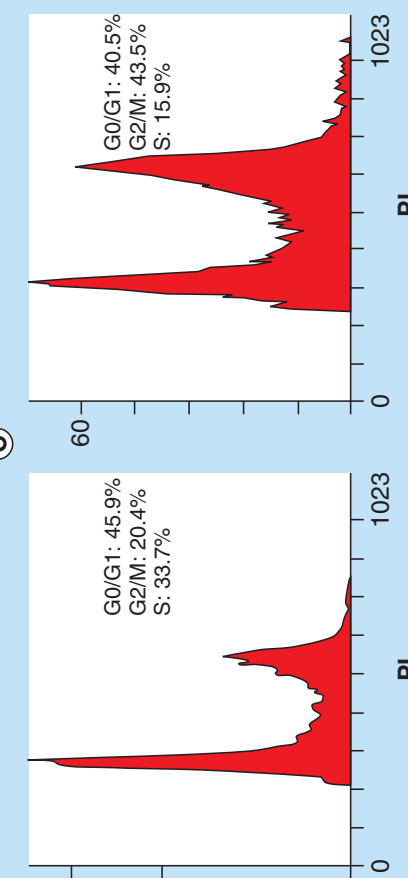

(1) $\stackrel{\infty}{\stackrel{\infty}{?}}$

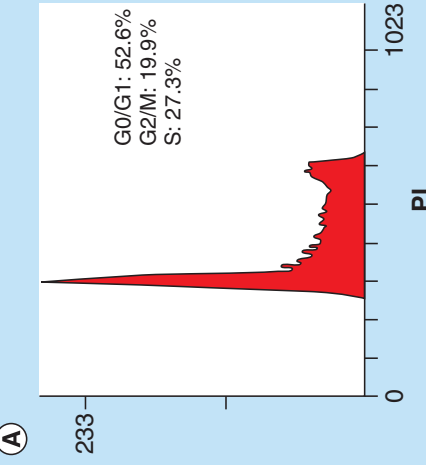

() $\stackrel{\infty}{=}$

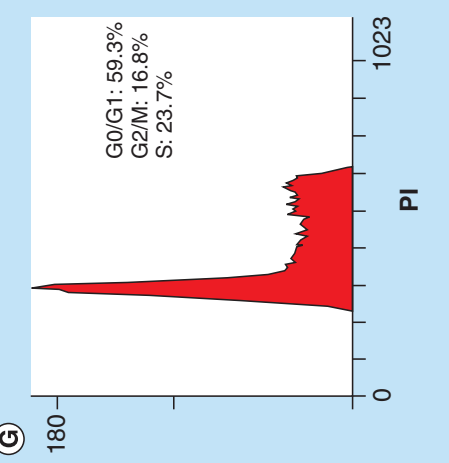

(4) $\stackrel{1}{\infty}$

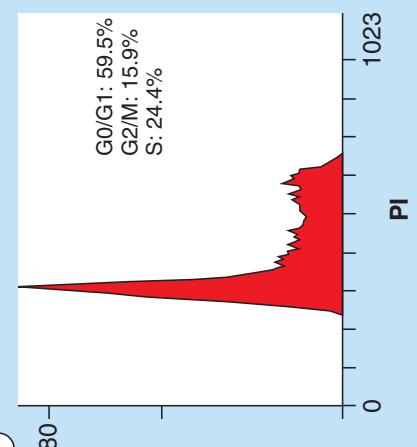

ஃำ

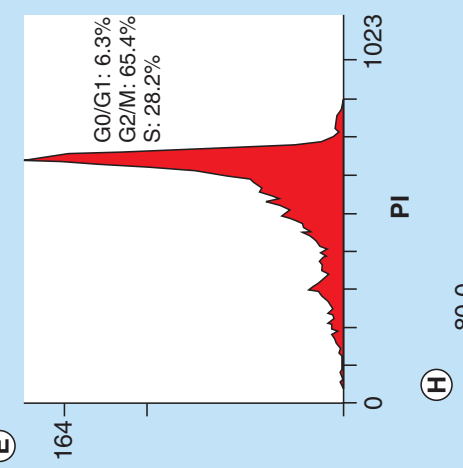

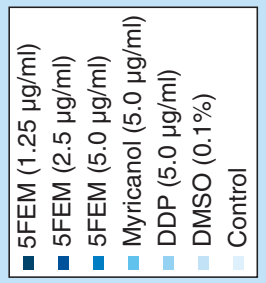

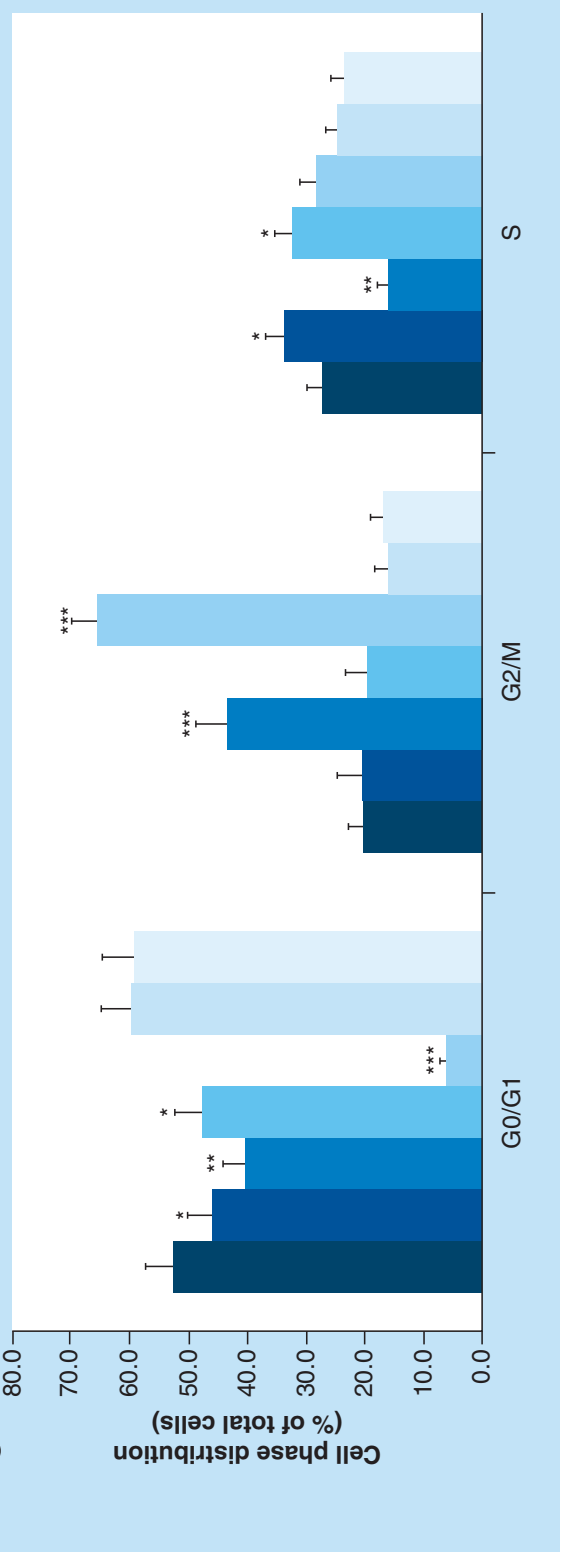

○.

主。ㅇํㅇ

월

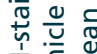

更

눙

苛

ํํㄹ

o

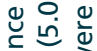

घै

造范

흔 뜽ㅇㅇ

प्षे

政

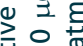

艎

¿

응

$\propto$

可社

है

रुำ

उ.

눙

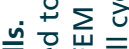

옹

웡워

至

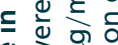

उ 32.

$\sum \Sigma \sum$ 培

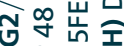

就语

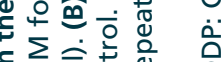

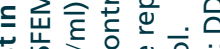

乌ั

\%

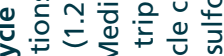

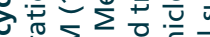

$\overline{\overline{0}}$

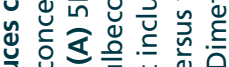

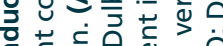

을

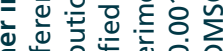

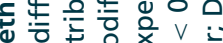

ते

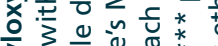

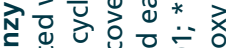

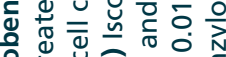

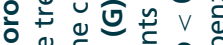

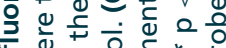

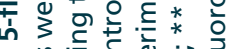

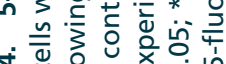

+

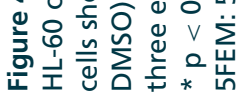




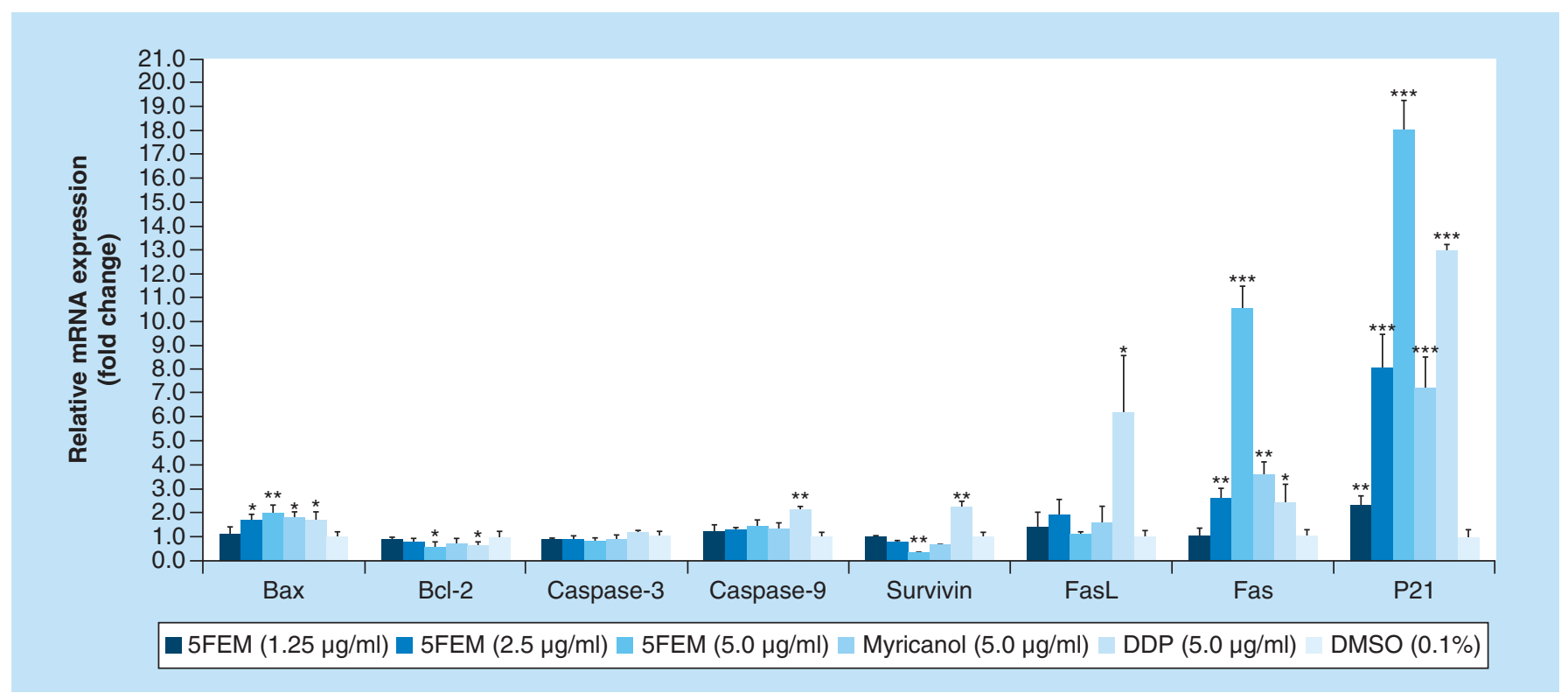

Figure 5. Effects of 5-fluorobenzyloxy ether on the mRNA expressions of caspase-3, caspase-9, Bax, Bcl-2, survivin, Fas, FasL and p21 in HL-60 Cells.

As shown, 5FEM significantly upregulated the mRNA expression levels of Bax, Fas and p21, and significantly downregulated the mRNA expression levels of $\mathrm{BCl}-2$ and survivin in a dose-dependent manner. All these gene expression changes are important in the apoptosis pathway. All data were expressed as mean \pm SE of three experiments and each experiment included triplicate repeats. * $\mathrm{p}<0.05 ; * * \mathrm{p}<0.01 ; * * * \mathrm{p}<0.001$ versus vehicle control.

5FEM: 5-fluorobenzyloxy ether; DDP:Cisplatin; DMSO: Dimethyl sulfoxide.

was increased significantly compared with that in the vehicle group ( $\mathrm{p}<0.001$; Figure 3$)$, indicating that 5FEM induced HL-60 cell apoptosis.

\section{Cell cycle analysis}

FCM was used to detect the effects of the tested compounds on cell cycle distribution. Different concentrations of 5FEM $(1.25,2.5$ and $5.0 \mu \mathrm{g} / \mathrm{ml})$ were used to treat HL- 60 cells for $48 \mathrm{~h}$, then cell populations in different cell cycle phases were detected. As a result, $5 \mathrm{FEM}$ led to disturbance of the cell cycle distribution in concentration-dependent manner (Figure 4). Specifically, the number of cells were increased significantly in G2/M population ( $\mathrm{p}<0.001)$, while decreased in the $\mathrm{G} 1$ and $S$ phase $(\mathrm{p}<0.05 \sim 0.01)$.

\section{mRNA expression of apoptosis-related genes in HL-60 cells}

Myricanol inhibited cell growth via the apoptotic pathway. We measured relative expression levels of eight apoptosisassociated genes by qRT-PCR. As shown in Figure 5, 5FEM significantly upregulated the mRNA expression levels of Bax, Fas and $p 21$, and significantly downregulated that of $B c l-2$ and survivin in a dose-dependent manner $(\mathrm{p}<0.05 \sim 0.001)$. All gene expression changes contributed to cell apoptosis.

\section{Expression level of apoptosis-associated proteins}

To clarify the genes participated in the 5FEM-mediated apoptosis of HL-60 cells, we measured the abundance of proteins (Bax, caspase-9, FasL, Bcl-2, and p21) in mitochondrial pathway of apoptosis. Results showed that pro-apoptotic proteins FasL, caspase-9, Bax and p21 were increased by 5FEM in all designed concentrations $(\mathrm{p}<0.05 \sim 0.01$; Figure 6). However the anti-apoptotic protein Bcl-2 was reduced by 5FEM ( $<<0.05)$. These results suggested that 5FEM could induce HL-60 cell apoptosis through upregulating pro-apoptotic proteins and downregulating anti-apoptotic protein.

\section{Discussion}

Plant-derived natural compounds have attractive pharmacological properties for cancer chemoprevention [19]. These plant preparations provide a source of active agents, and are safe and inexpensive strategies of chemoprevention [20]. 


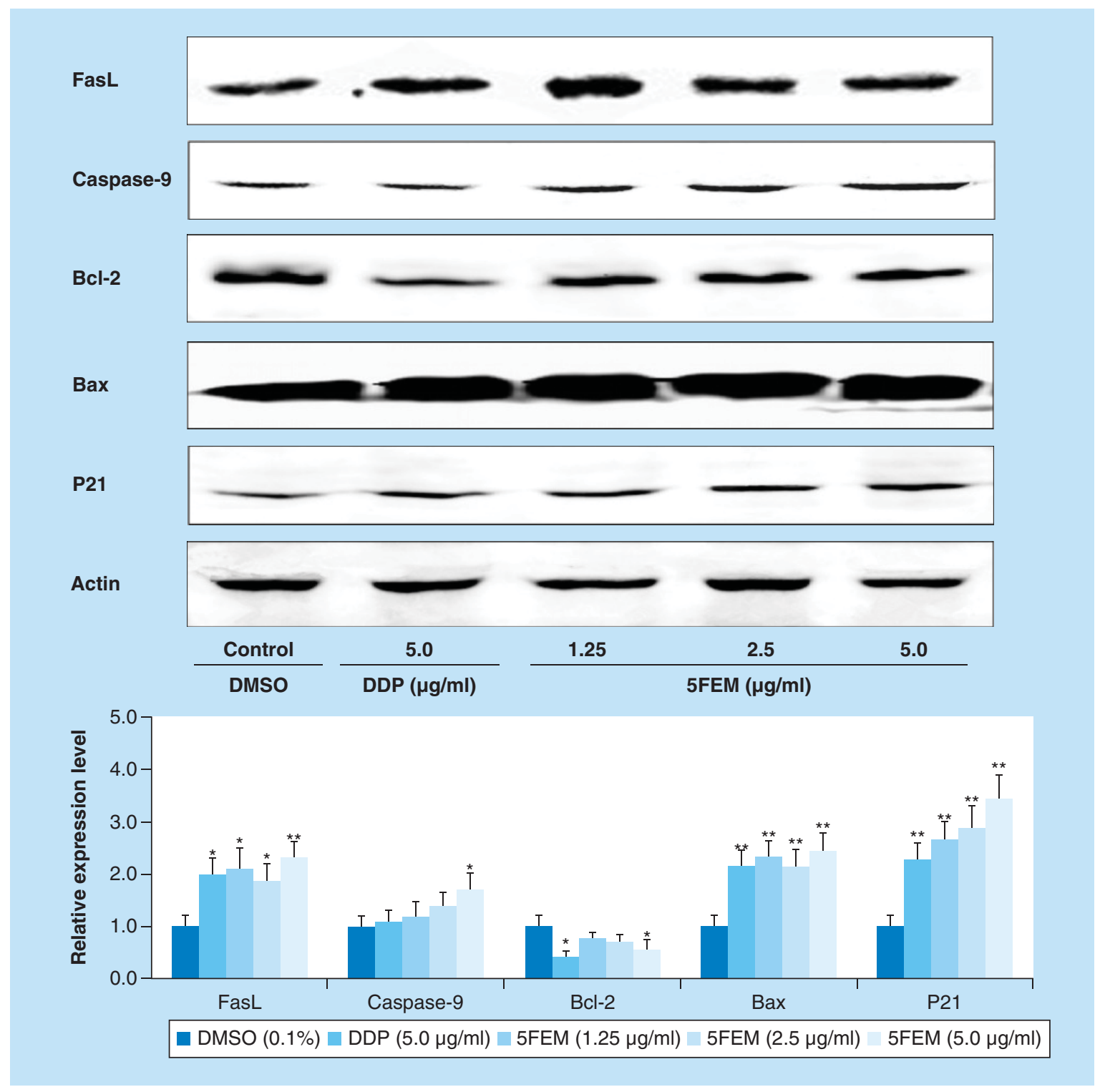

Figure 6. Western blot analysis of apoptosis-related proteins.

Total protein extracts were prepared after treatment with different concentrations of 5FEM $(1.25,2.5$ and $5.0 \mu \mathrm{g} / \mathrm{ml})$ in $\mathrm{HL}-60$ cells for $48 \mathrm{~h}$, and were analyzed by western blotting with antibodies against FasL, Caspase-9, Bcl-2, Bax, p21 and actin. All data were expressed as mean \pm SE of three experiments and each experiment included triplicate repeats.

$* \mathrm{p}<0.05 ; * * \mathrm{p}<0.01$ versus vehicle control.

5FEM: 5-fluorobenzyloxy ether; DDP: Cisplatin; DMSO: Dimethyl sulfoxide.

Natural products are important and valuable resources for drug development, with a long history of use in treating human ailments, particularly for almost all kinds of cancer [21]. Early drug discovery was based on screening of a large number of natural and synthetic compounds. In modern screening, computer and other molecular biology techniques have been used [22]. Although different techniques have discovered new and potential drugs, natural products remain one of the best reservoirs for the discovery of new drugs.

Tumor therapy includes inhibiting tumor cell proliferation, inducing apoptosis of tumor cells, inducing tumor cell differentiation, reversal of tumor multidrug resistance, inhibiting tumor vasculature formation and enhancing immunity [4]. It was found that cell apoptosis was the most closely related to tumor occurrence. Therefore, the induction of tumor cell apoptosis is an important mechanism for targeted cancer therapy [23]. 
Apoptosis is a process of programmed cell death that occurs in multicellular organisms. Any dysregulation of apoptosis can result in abnormality, disease and death. Cancer is a result of uncontrolled cell proliferation and apoptosis dysregulation [24]. Therefore, the induction of apoptosis is a highly desirable mechanism for cancer treatment [25]. The present results showed that 5FEM, obtained by chemical modification of myricanol at the $\mathrm{OH}(5)$ position with fluorobenzyloxy ether, significantly inhibited the growth of A549, HepG2 and HL-60 cells in a dose-dependent manner. The inhibitory effect on HL-60 cells was particularly evident. 5FEM induced the apoptosis of HL-60 cells and increased the G2/M population in a concentration-dependent manner. Further, it significantly upregulated the expression levels of caspase-9, Bax, Fas, FasL and p21, and downregulated the levels of Bcl-2 and survivin in a dose-dependent manner. These changes associated with apoptosis [26,27].

\section{Conclusion}

The present results indicate that 5FEM exerts antiproliferative action against A549, HepG2 and HL-60 cancer cell lines. The results also showed that the antitumor effect of 5FEM was better than that of myricanol. Although diarylheptanoid compounds and their anticancer action have been extensively investigated, similar results concerning 5FEM have not been published previously. 5FEM induced cell cycle disturbance in a concentration-dependent manner and apoptosis via the activation of the mitochondrial pathway. The current results indicate that 5FEM could be a suitable candidate for the development as a novel potential anticancer agent than myricanol. But, why the introduction of fluorobenzyloxy ether at the $5-\mathrm{OH}$ position could render the prodrug more active than the parent compound? The exact mechanism is not clear. Further studies (e.g., xenograft animal models and gene knockout experiments) should be performed in vivo.

\section{Future perspective}

5FEM was obtained by chemical modification of myricanol with fluorobenzyloxy ether at the $\mathrm{OH}(5)$ position. The chemical modification investigation of myricanol can provide a clue for the accumulation of compounds of medicinal interest from the plant-derived natural compounds in the future, which enable the further anticancer study, the structure optimization and the structure-activity relationship study toward new drug leads. The results present here indicate that the anticancer action of the novel myricanol derivatives against the cell line HL-60, via apoptosis, supposes a great advantage for a future therapeutic use. In future, new antitumor drugs can be designed applying new synthetic methods in order to increase their bioactivity for targeted cancer therapy.

\section{Executive summary}

- 5-fluorobenzyloxy ether (5FEM) was obtained by chemical modification of myricanol with fluorobenzyloxy ether at the $\mathrm{OH}(5)$ position.

- 5FEM significantly inhibited the growth of HL-60 cells in a dose-dependent manner.

- The antitumor effect of 5FEM was better than that of myricanol.

- 5FEM induced HL-60 cell apoptosis, increased the G2/M population and decreased that of the G1 and S phases.

- 5FEM significantly upregulated the mRNA expression levels of Bax, Fas and p21, and significantly downregulated that of $\mathrm{BCl}-2$ and survivin in a dose-dependent manner. All gene expression changes contributed to cell apoptosis.

- 5FEM increased the pro-apoptotic proteins expression levels of the FasL, caspase-9, Bax and p21, and reduced that of Bcl-2. These results suggested that 5FEM could induce HL-60 cell apoptosis.

Financial \& competing interests disclosure

This work was supported by the Science and Technology Foundation of Zhejiang Province (numbers 2013 F50020 and 2017C33169). The authors have no other relevant affiliations or financial involvement with any organization or entity with a financial interest in or financial conflict with the subject matter or materials discussed in the manuscript apart from those disclosed.

No writing assistance was utilized in the production of this manuscript.

\section{Open access}

This work is licensed under the Attribution-NonCommercial-NoDerivatives 4.0 Unported License. To view a copy of this license, visit http://creativecommons.org/licenses/by-nc-nd/4.0/ 


\section{References}

Papers of special note have been highlighted as: $\bullet$ of interest; $\bullet \bullet$ of considerable interest

1. Chen W-Q, Zheng R-S, Zhang S-W, Zhao P, Zeng H-M, Zou X-N. Report of cancer incidence and mortality in China, 2010. Ann. Transl. Med. 2, 61 (2014).

2. Chen W-Q, Zheng R-S, Baade P-D et al. Cancer statistics in China, 2015. CA Cancer J. Clin. 66, 115-132 (2016).

3. Teras LR, DeSantis CE, Cerhan JR, Morton LM, Jemal A, Flowers CR. 2016US lymphoid malignancy statistics by World Health Organization subtypes. CACancer J. doi:10.3322/caac.21357 (2016) (Epub ahead of print).

- Lymphoid neoplasms are the sixth leading cause of cancer death in the United States.

4. Pistollato F, Giampieri F, Battino M. The use of plant-derived bioactive compounds to target cancer stem cells and modulate tumor microenvironment. Food Chem. Toxicol. 75, 58-70 (2015).

5. Hutter JJ. Childhood leukemia. Pediatr. Rev. 31(6), 234-241 (2010).

6. Zimmermann C, Meurer MI, Grando LJ, Gonzaga Del Moral JÂ, da Silva Rath IB, Schaefer Tavares S. Dental treatment in patients with leukemia. J. Oncol. 115(4), 308-315 (2015).

7. Mateen S, Raina K, Agarwal R. Chemopreventive and anti-cancer efficacy of silibinin against growth and progression of lung cancer. Nutr. Cancer 65, 3-11 (2013).

8. Molnár J, Szebeni GJ, Csupor-Löffler B et al. Investigation of the antiproliferative properties of natural sesquiterpenes from Artemisia asiatica and Onopordum acanthium on HL-60 cells in vitro. Int. J. Mol. Sci. 17, 1-15 (2016).

- Interesting research article of plant extracts in the research into novel anticancer drugs.

9. Ambrož M, Matoušková P, Skarka A, Zajdlová M, Žáková K, Skálová L. The effects of selected sesquiterpenes from Myrica rubra essential oil on the efficacy of doxorubicin in sensitive and resistant cancer cell lines. Molecules 22(6), pii:E1021 (2017) (Epub ahead of print).

10. Zhang X, Huang H, Zhang Q et al. Phytochemical characterization of Chinese Bayberry (Myrica rubra Sieb. et Zucc.) of 17 cultivars and their antioxidant properties. Int. J. Mol. Sci. 166, 12467-12481 (2015).

11. Kuo PL, Hsu YL, Lin TC, Lin LT, Lin CC. Induction of apoptosis in human breast adenocarcinoma MCF-7 cells by prodelphinidin B-2 3,3'-di-O-gallate from Myrica rubra via Fas-mediated pathway. J. Pharm. Pharmacol. 5611, 1399-1406 (2004).

-• An interesting research article regarding the bark of Myrica rubra is used in Chinese folk medicine.

12. Dai G-H, Tong Y-L, Chen X, Ren Z-M, Yang F. In vitro anticancer activity of myricanone in human lung adenocarcinoma A549 cells. Chemotherapy 60, 81-87 (2014).

13. Konno K, Sawamura R, Sun Y et al. Antiviral activities of diarylheptanoids isolated from Alpinia officinarum against respiratory syncytial virus, poliovirus, measles virus, and herpes simplex virus type 1 in vitro. Nat. Prod. Commun. 6(12), 1881-1884 (2011).

14. Lee WS, Kim JR, Im KR, Cho KH, Sok DE, Jeong TS. Antioxidant effects of diarylheptanoid derivatives from Alnus japonica on human LDL oxidation. Planta Med. 71, 295-299 (2005).

15. Aguilar MI, Rovelo R, Verjan JG et al. Anti-inflammatory activities, triterpenoids, and diarylheptanoids of Alnus acuminata ssp. arguta. Pharm. Boil. 49, 1052-1057 (2011).

16. Dai G-H, Meng G-M, Tong Y-L et al. Growth-inhibiting and apoptosis-inducing activities of myricanol from the bark of Myrica rubra in human lung adenocarcinoma A549 cells. Phytomedicine 21, 1490-1496 (2014).

-. Evidences that the myricanol inhibiting human lung adenocarcinoma via apoptosis pathway.

17. Dai G-H, Tong Y-L, Chen X et al. Myricanol induces apoptotic cell death and anti-tumor activity in non-small cell lung carcinoma in vivo. Int. J. Mol. Sci. 16, 2717-2731 (2015).

18. Whyte L, Huang YY, Torres K, Mehta RG. Molecular mechanisms of resveratrol action in lung cancer cells using dual protein and microarray analyses. Cancer Res. 67, 12007-12017 (2007).

19. Tuorkey MJ. Cancer therapy with phytochemicals: present and future perspectives. Biomed. Environ. Sci. 28, 808-819 (2015).

- Future perspectives the plant-derived natural compounds for cancer prevention.

20. Millimouno FM, Dong J, Yang L, Li J, Li X. Targeting apoptosis pathways in cancer and perspectives with natural compounds from mother nature. Cancer Prev. Res. 7, 1081-1107 (2014).

- Targeting apoptosis pathways in cancer with natural compounds are safe and inexpensive strategies of chemoprevention.

21. Srivastava SK, Arora S, Averett C, Singh S, Singh AP. Modulation of microRNAs by phytochemicals in cancer: underlying mechanisms and translational significance. Biomed. Res. Int. 2015, 848710 (2015).

22. Patwardhan B. Ethnopharmacology and drug discovery. J. Ethnopharmacol. 100, 50-52 (2005).

23. Modica-Napolitano JS, Weissig V. Treatment strategies that enhance the efficacy and selectivity of mitochondria-targeted anticancer agents. Int. J. Mol. Sci. 16, 17394-17421 (2015).

-. The induction of tumor cell apoptosis is an important mechanism for targeted cancer therapy.

24. Czubaty A, Piekielko-Witkowska A. Protein kinases that phosphorylate splicing factors: roles in cancer development, progression and possible therapeutic options. Int. J. Biochem. Cell. Biol. doi:10.1016/j.biocel.2017.05.024 (2017) (Epub ahead of print). 
25. Reed JC, Pellecchia M. Apoptosis-based therapies for hematologic malignancies. Blood 106, 408-418 (2005).

26. Huang Y-C, Kuo C-L, Lu K-W et al. 18 $\alpha$-glycyrrhetinic acid induces apoptosis of HL-60 human leukemia cells through caspases- and mitochondria-dependent signaling pathways. Molecules 21(7), pii:E872 (2016) (Epub ahead of print).

27. Shi M, Ren X, Wang X et al. A novel combination of oridonin and valproic acid in enhancement of apoptosis induction of HL-60 leukemia cells. Int. J. Oncol. 482, 734-746 (2016). 
